分 析

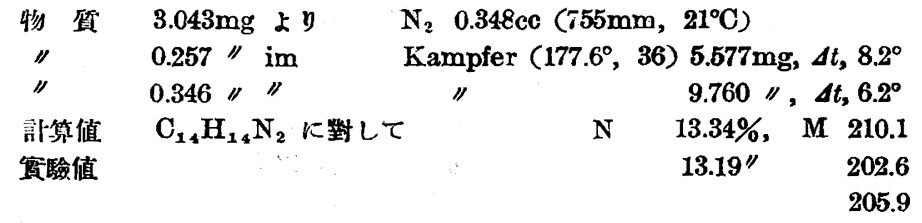

（東北帝國大學工學部化學工學科研究室）（昭和 8 年 5 月 23 日受理）

\title{
トリーアリルアミノーエチレンに關する研究（第4 啹）
}

\section{トリー(ーートリルアミノ)-エチレンと硫黄との飺融}

\section{柴田林之助 ・西 鐵之輔}

トリーフェニルアミノーエチレンと硫黄とを熔础する時得らる〉前報 $[I] 〜[V]$ なる 5 物質に就て見るに若 しも〔I]又はlV]のベンゾール核にイミノ基のオルトの處にメチル基があるならば其等よりインヂゴを諉導 する事容易なるべし。

[I]<smiles>C1CCC(CNCCNC2CCCCC2)CC1</smiles>

[V]<smiles>O=C(NC1CCCCC1)C(=O)NC1CCCCC1</smiles>

是れを以て著者等はアニリンの代りに ○ートルイヂンを探り是れをトリクロルエチレンと縮合して得るトリー (ロートリルアミノ)ーエチレンを硫黄と螾融する事に目手せり。

○ートルイヂンとトリクロルエチレンとを石灰乳の存在にて縮合して得ろ主生成物はトリー(0ートリルアミノ)-

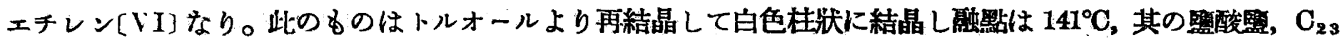
$\mathrm{H}_{25} \mathrm{~N}_{3} \mathrm{HCl}$ は稀薄エタノールより白色柱狀に結晶し融點は $203^{\circ} \mathrm{C}$ (分解) なり。副生成物としては次の 5 物 質 (VII〜XI) を分離する事を得。夫等は收量何れる微量なれどもその中にて融點 $115 〜 6^{\circ} \mathrm{C}$ の物賀(VII) は 注目に值す。それは色を有するのみならず oートルイデッの代りに $p$-トルイデンを用ふる時の反䳡が其の主生 成物は却つて是れに相當する物資なるが如くに起るを以てなり。

\begin{tabular}{|c|c|c|c|c|c|}
\hline VII & 䖲 點 & $115 \sim 6^{\circ} \mathrm{C}$ & 色 & 黃 & 物質 [VII] はその分析の結果は $\mathrm{C}_{23} \mathrm{H}_{23} \mathrm{~N}_{3}$ なる \\
\hline VIII & य & $210 \sim 212$ & $"$ & 銀 白 & 式を要求するけれどもその構造をば 未げ決定するに \\
\hline IX & " & $145 \sim 147$ & " & 白(杜狀) & \\
\hline $\mathbf{x}$ & " & 251 & " & 白(針狀) & 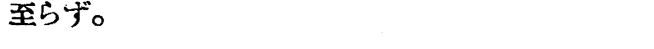 \\
\hline XI & " & 213 & " & 白(杜狀) & トリー(o-トリルアミノ)ーエチレンと硫黄との混 \\
\hline
\end{tabular}

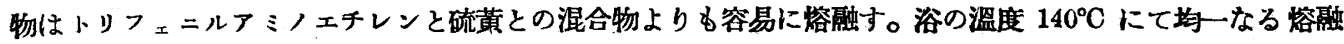
物となせる後は $130 〜 135^{\circ} \mathrm{C}$ に保ち總計 1 時間の後融成物を冷却しトリフェニルアミノメチレンの場合とほ 5゙同一なる處理（第 2 圖照照）

により

\begin{tabular}{|c|c|c|c|c|c|c|c|c|}
\hline$\left.R_{4}\right)$ & ょり & 絬晶 & & 融點 & $118^{\circ} \mathrm{C}$ & 色 & 赫黄 & \\
\hline & 上り & & II & " & 83 & & 橙蔹 & {$[\mathrm{XIII}]$} \\
\hline & & & III & "I & 69 & & 白 & [XII] \\
\hline
\end{tabular}




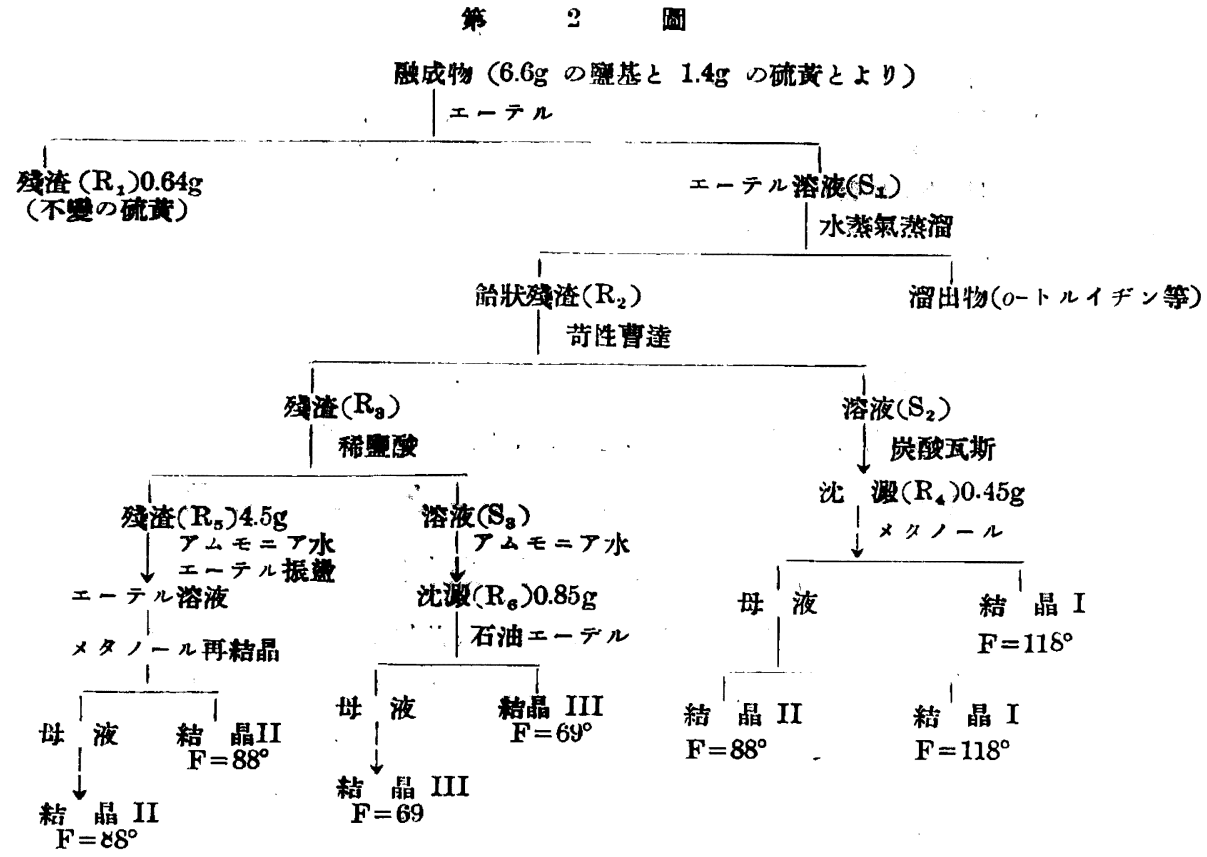

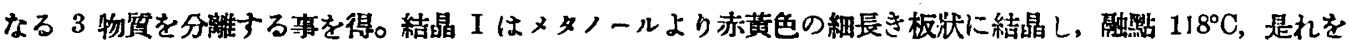
分析すれば $\mathrm{C}_{18} \mathrm{H}_{16} \mathrm{~N}_{2} \mathrm{~S}_{2}$ に一致しヂチオオキザルー(のートルイド)[XIV]なり。郎ちヂチオオキザニリド[III)

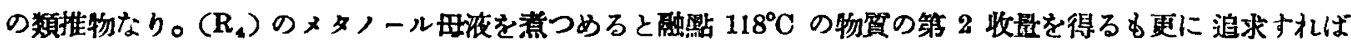

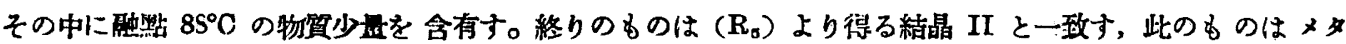

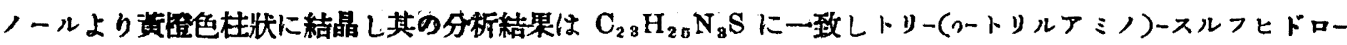
エチレン[XIII] なり。トリーフェニルアミノースルフヒドロ-エチレン [II] の類推物なり。されどその基性

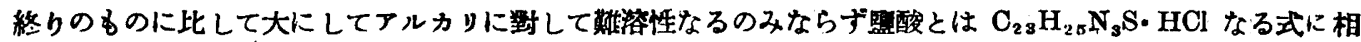

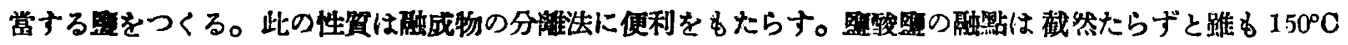

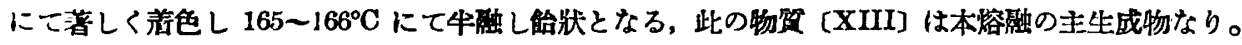

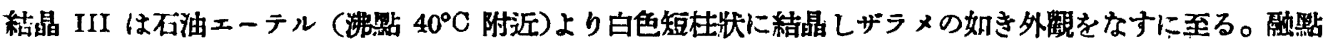
は $69^{\circ} \mathrm{C}$ 其の分析結果は $\mathrm{C}_{18} \mathrm{H}_{18} \mathrm{~N}_{2}$ に一致しヂ-(oートリルアミノ)-エチレン〔XII]にしてヂフェニルアミ ノェチレン[I] の類推物なり。

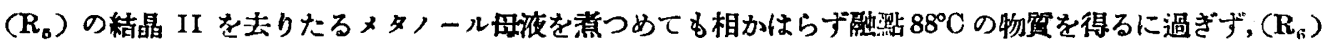

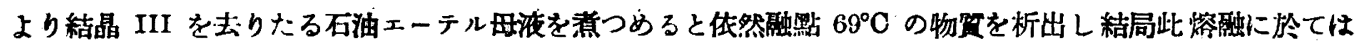
以上. 3 物筫を生成するるのにしてオキザニリト及チオオキザニリドに相賞する物留の生成は認めず, 郎ち換官

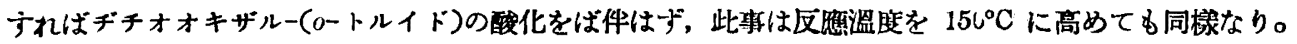

$$
\text { 筫 匳 } の \text { 部 }
$$

I. ○ートルイチンとトリクロルェチレンとの縮合ルトルイヂン $160 \mathrm{cc}(134 \mathrm{~g})$, トリクロルエチレン $50 \mathrm{cc}$, 炭酸ナトッウム $70 \mathrm{~g}$ 及び石灰乳 (55g の石灰と 250 - 300 cc の水とにて作れる) の混合物を二っロの> 


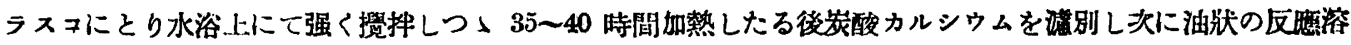

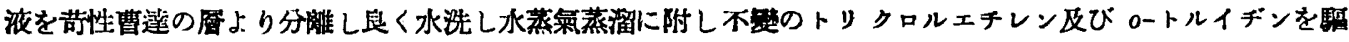

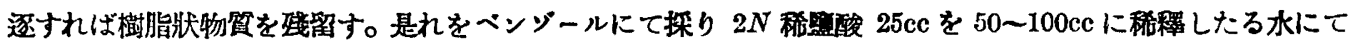

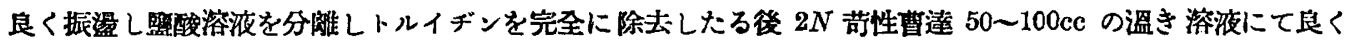
振壍すると一度析出せる縮合生成物は再びベンゾール溶液中にとけ迈みて消えてゆく，ベンジール溶液中に不

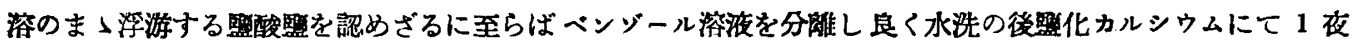

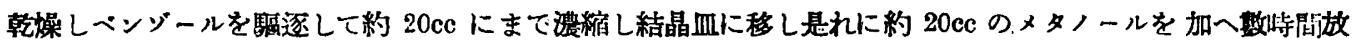

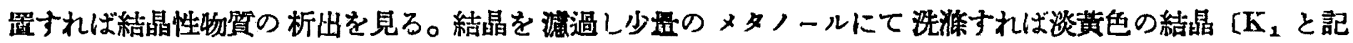

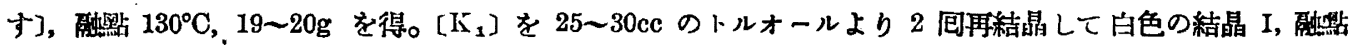

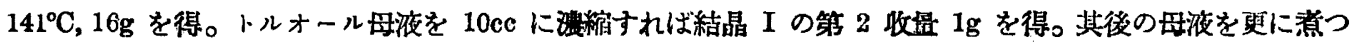
め乾涸の後メタノールより再結晶を繰返すと黄色の結晶 II, 融㢦 $115^{\circ} \mathrm{C}, 0.1 \mathrm{~g}$ を得。

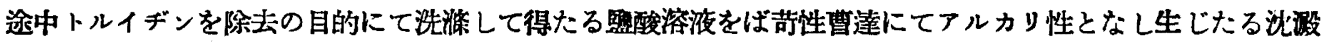
をべンゾールにて抽出し結晶 1 をとりたると同一操作を繰り返へしたるす結晶性物筫をとり出す事を得ず。

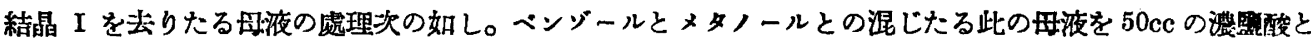
$50 \mathrm{cc}$ の水とにて虎理の後水浴上に 30 ６0 分溫め，後 $1.5 \sim 2 l$ に水を以て稀釋し水浴上にて溫め濾別す，同

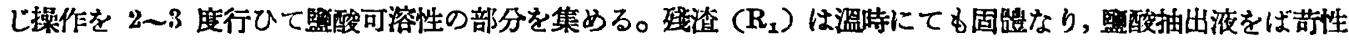
曹達にてアルカリ性となし生じたる沈澱をべンジールにて探り結晶 I を得ると同一の操作をほどこして其の 第 3 の收量 $2 \mathrm{~g}$ を得。

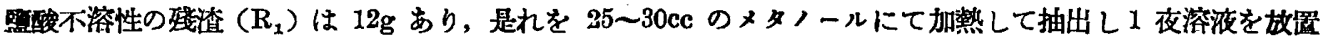
すれば褐色の結晶 $\left[\mathrm{K}_{2}\right] 0.7 \mathrm{~g}$ を得，是れをべンジール 10 〜 $15 \mathrm{cc}$ にて再結晶すれば結晶 III $0.3 \mathrm{~g}$ を得, 是れ をトルオールより再結晶 2 国にて銀白色薄板狀の結晶, 融點 $210 \sim 212^{\circ} \mathrm{C}$ なり。結晶 III の母夜はベンゾー 儿驅逐の後メタノールより再結晶 $2 \sim 3$ 回を經て白色杜狀の融然 $145 \sim 147^{\circ} \mathrm{C}$ なる結晶 IV $0.2 \mathrm{~g}$ を得る。

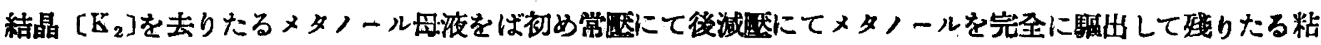

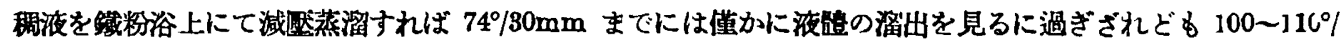

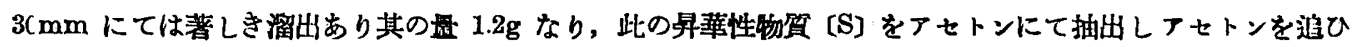

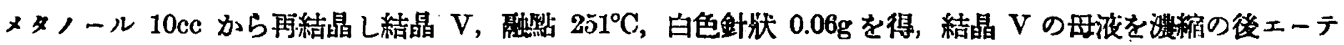

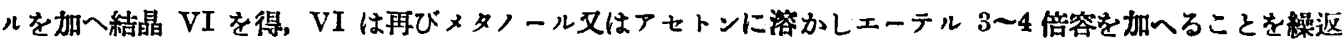

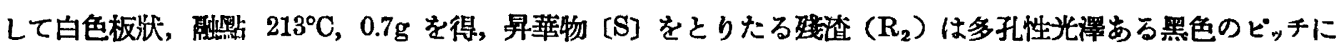
して $8 \mathrm{~g}$ あり。间收し得る 0 -トルイヂンの些は 75〜80cc なり。

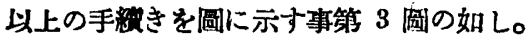

斯くて得る物筫中霆要なるは結晶 I 並に II にして其他は概ね分解の結果の第 2 次的生成物にして其盐も 亦大ならず，大切なる事は反て $\left(\mathbf{R}_{\mathbf{1}}\right)$ の損はざる處理法なる可し，各生成物の性貿を記する事下の如し。

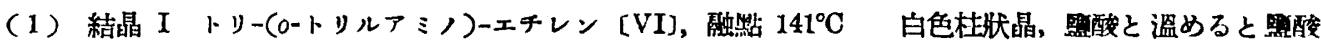

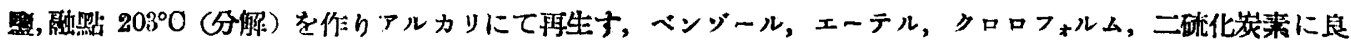

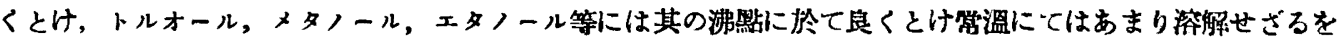




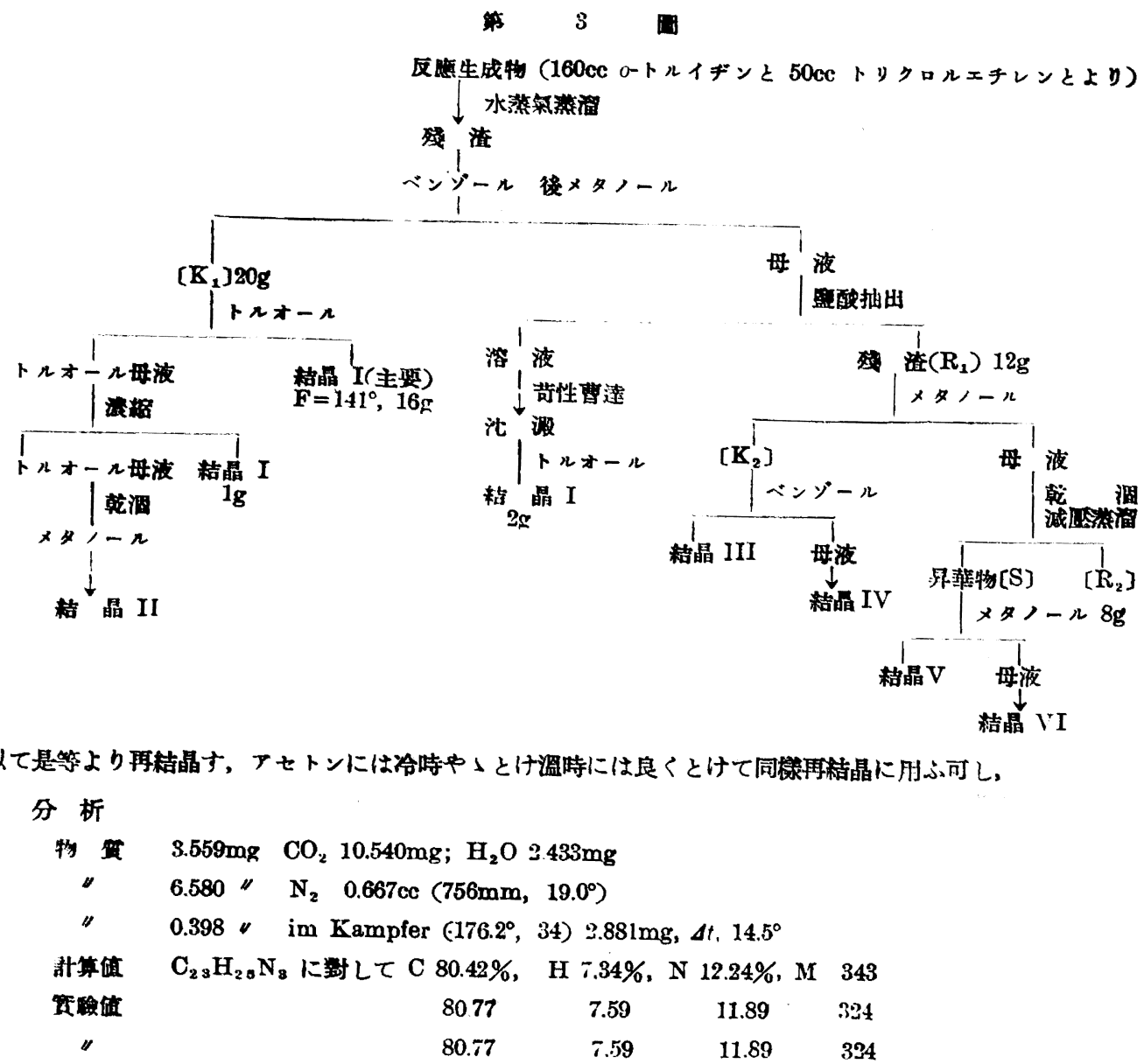

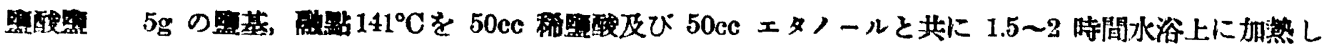

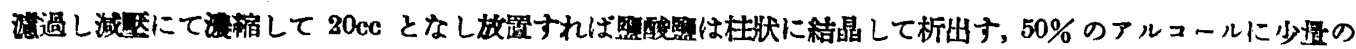

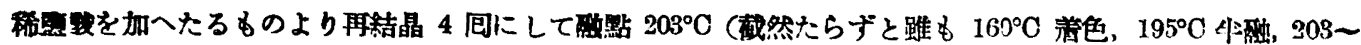
$205^{\circ} \mathrm{C}$ にて分解しつょ烙俩な) 白色柱狀晶 $3 \mathrm{~g}$ を得。

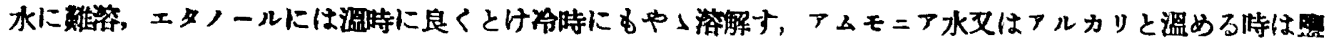
基, 能點 $141^{\circ} \mathrm{C}$ を遊睢す。

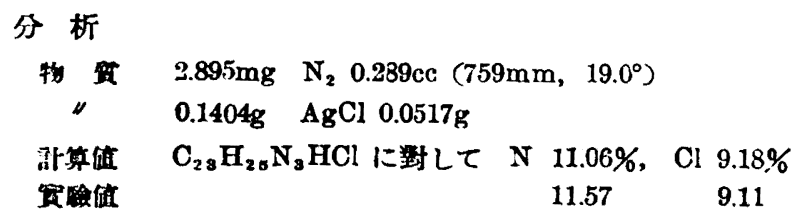

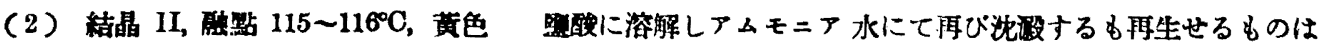

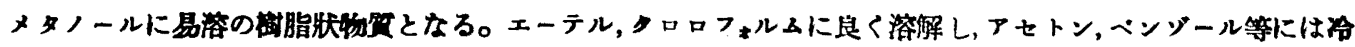

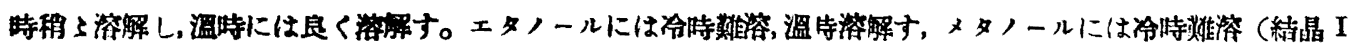




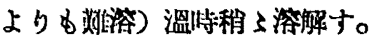

分 析

物 留 $4.036 \mathrm{mg}, \mathrm{CO}_{2} 11.953 \mathrm{mg} \mathrm{H} \mathrm{H}_{2} \mathrm{O}, 2.459 \mathrm{mg}$

" $4.371 \mathrm{mg}, \mathrm{N}_{2} \quad 0.470 \mathrm{cc}\left(757 \mathrm{~mm}, 15.6^{\circ}\right)$

忛算值 $\mathrm{C}_{2 \mathrm{~S}} \mathrm{H}_{23} \mathrm{~N}_{3}$ に對して $\mathrm{C} 80.94 \% ， \mathrm{H} \mathrm{6.80 \% ，} \mathrm{N} \mathrm{12.32 \%}$

定酸值 $80.75 \% \quad 6.77 \% \quad 13.15 \%$

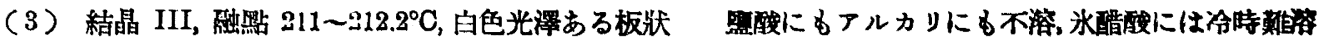

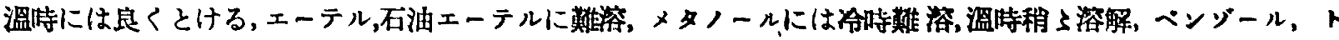

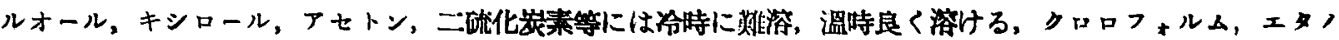
一ルには冷時稍々溶け溫特には溶磪す。

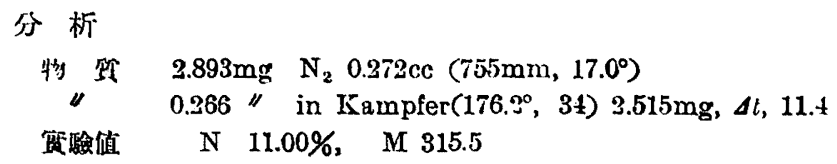

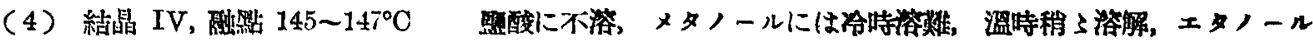

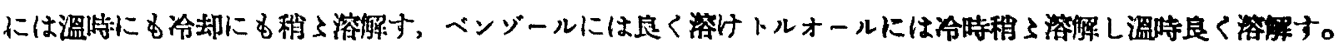
分 析

物 贸 $4.621 \mathrm{mg} \quad \mathrm{N}_{2} 0.311 \mathrm{cc}\left(757 \mathrm{~mm}, 17.0^{\circ}\right)$

" $0.322 "$ in Kampfer $\left(176.2^{\circ}, 34\right) 3.971 \mathrm{mg} \Delta t, 8.5^{\circ}$

筮嘫值 N 7.89\%， M 324.4

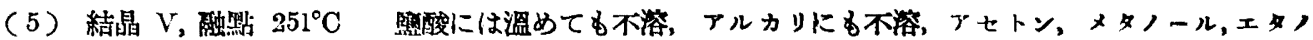

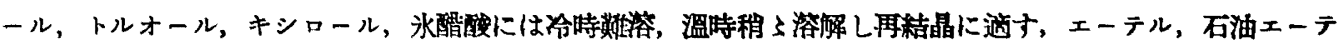
ル，二硫化炭素，醀酸エチル，クロロフォルムには難搭。

分 䉼

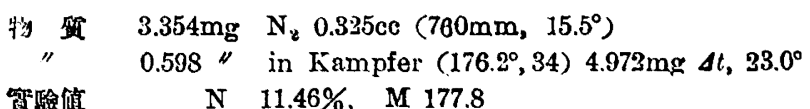

筫驗做 $\quad \mathrm{N} \quad 11.46 \% ， \quad$ M 177.8

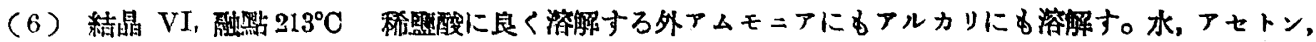
メタノール，エタノール，氷醋酸等に溶解し，エーテル，石油エーテル，クロロフォルム，二疏化炭素，デッッ゙

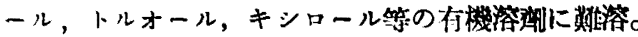

分 析

$\begin{array}{llll}\text { 特 } & 5.100 \mathrm{mg} & \mathrm{N}_{2} & 0.420 \mathrm{cc}\left(757 \mathrm{~mm}, 17.3^{\circ}\right) \\ \text { " } & 0.395 \text { " in Kampfer }\left(177.6^{\circ}, 36\right) 3.497 \mathrm{mg} \quad \Delta t, 11.8^{\circ}\end{array}$

亩磁值 N $9.66 \% ，$ M 344.8

○ートルイヂンとトリクロルエチレンとの縮合に關し猛ほ次の 3 蚾驗を行ひたるす洪の結果は有卧にあらず。

i） o-トルイヂン $10.7 \mathrm{~g}(0.1 \mathrm{~mol})$,トリクロルエチレン $4 \mathrm{~g}(0.03 \mathrm{~mol})$, 苛性昌蒸 $(16 \%) \simeq 0 \mathrm{cc}(0.1 \mathrm{~mol})$ を封

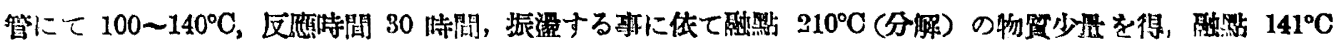

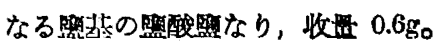

ii）

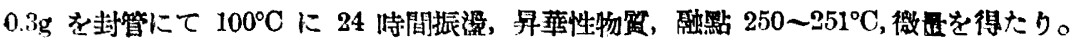


iii） ヒ-トルイヂン $50 \mathrm{cc}$, トリクロルエチレン $20 \mathrm{cc}$, 炭酸加里 $30 \mathrm{~g}$, 銅粉 $1.1 \mathrm{~g}$, 監化第一銅 $2 \mathrm{~g}$ を三っロ

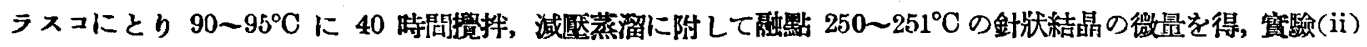
と同一絓果の如し。

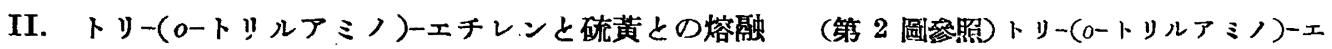
チレン $6.6 \mathrm{~g}(0.02 \mathrm{~mol})$ と硫黄 $1.4 \mathrm{~g} \cdot(0.04 \mathrm{~mol})$ との（重量比 $5: 1)$ 混合物を乳錸にて良く替合せ圆底フラス

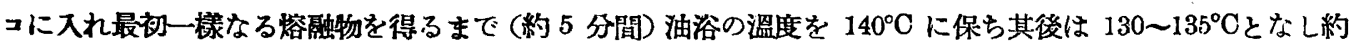
55 分間時々硝子棒にて撜拌しながら加熱す。此の時硫化水素 (醌酸鉛紙にて检出) 及び ロム酸加里と硫酸とにて檢出)の發生あり。冷却の後赤撜色粘䅕なる融成物に 10cc のエーテルを加へ濾過し 15ec のエーテルにて洗淮 3 包にして濾液か治んど無色となる。琵盉 $\left(\mathrm{R}_{1}\right)$ と溶液 $\left(\mathrm{S}_{1}\right)$ とに分離す。 $\left(\mathrm{R}_{1}\right)$ を 溫度 $40^{\circ} \mathrm{C}$ に於て $2 N$ 苛性曹道にて抽出するる溶解する成分を認めず(炭酸瓦斯を通ずるる沈澱起らず) 其の

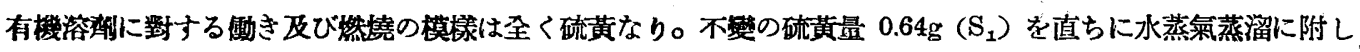
エーテル及び ○ートルイ゙ンを䮠逐し赤褐色の餄狀物質 $\left(\mathrm{R}_{2}\right)$ を得, 是れを少量のエーテルにてビーカーに移 しェーテルを驅逐したる後 $2 N$ 苛性曹達 $25 \mathrm{cc}$ を上て温度 $60^{\circ} \mathrm{C}$ 於て 30 分間宛溫めて抽出する事を 3 尼行 ひ苛性曹達溶液をば餄胲物賀より倾淐及び憈過によりて分離す。斯くて $\left(\mathrm{R}_{3}\right)$ と $\left(\mathrm{S}_{2}\right)$ とを得。 $\left(\mathrm{S}_{2}\right)$ に炭酸瓦

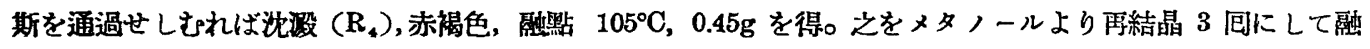
點 $118^{\circ} \mathrm{C}$ となる。メタノール母夜を斗容にまで濃樎する事を 2 包に行ひ析出する物質を检するに融點 $118^{\circ} \mathrm{C}$ を示すのみなり，然るに此の母液を更に蒸發乾涸して少量のエーテルを以て抽出せる溶液に同签のメタノール を加一放置すると僅少なれど其の珤點 $86^{\circ} \mathrm{C}$ なる物貿を得。

$\left(\mathbf{R}_{\mathbf{8}}\right)$ をば水洗してアルカリを良く除去したる後 $2 N$ 稀監酸 $25 \mathrm{cc}$ を以て溫度 60 〜 $0^{\circ} \mathrm{C}$ にて 30 分問宛 3 问操返し抽出すれば餄狀のるのが粉末狀となる, 濾別して $\left(\mathbf{S}_{3}\right)$ と $\left(\mathbf{R}_{5}\right)$ となる。

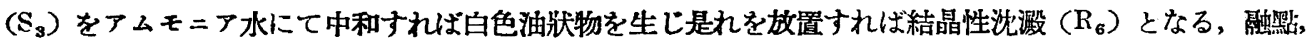

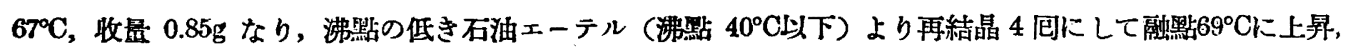
杜狀, 殆んど無色, 石油エーテルの母液を煮つめて析出し來るものはやはり $69^{\circ} \mathrm{C}$ の融默を示し同一物なり。

\begin{tabular}{|c|c|c|c|c|c|c|}
\hline \multirow{3}{*}{ 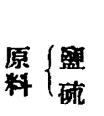 } & & 實驗 1 & 2 & 3 & 4 & アムモニア水とエーテルに \\
\hline & 基(g) & 6.6 & 7.8 & 85 & & \multirow{2}{*}{ 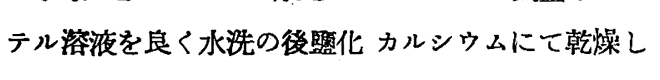 } \\
\hline & 黄 & 1.4 & 1.6 & 8 & & \\
\hline \multirow{2}{*}{\multicolumn{2}{|c|}{$\begin{array}{l}\text { 反飾 偲度 }\left({ }^{\circ} \mathbf{C}\right) \\
\text { 反應 時間(分) }\end{array}$}} & $30-5$ & $125-30$ & & -5 & エーテルを駱逐し 黃褐色飴狀物賀を得, 是れに少量 \\
\hline & & 60 & 60 & \pm 0 & & ルを加へ摩祭すれば黃色の 結昆性粉末, \\
\hline \multicolumn{2}{|c|}{ 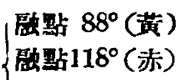 } & $\begin{array}{l}4.5 \\
0.45\end{array}$ & & & & 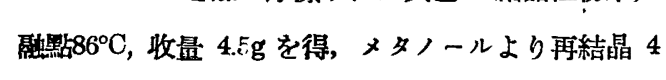 \\
\hline \multicolumn{2}{|c|}{ 融點 $69^{\circ}$ (白) } & 0.85 & 1.3 & 3.8 & 1.35 & 四にして融點 $88^{\circ} \mathrm{C}$, 橙黄色杜狀晶となる,メタノール \\
\hline & & 0.64 & 0.8 & 0.8 & 0.8 & D結晶を得。 \\
\hline
\end{tabular}

上上の操作を圆示すれば第 2 岡の如し。唒ほ收量に關しては上表の如し。

III. 反應生成物の性質

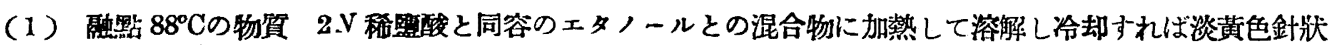
の酸整を生ず。溫アルカリ（2N）に浴易く炭酸瓦斯にて再生す。冷アルカリには融㫮 $118^{\circ} \mathrm{C}$ の物貿に比し

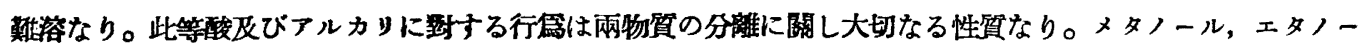


ルには冷時難溶，溫時には可溶にして再結晶に適す。橙黄色小柱狀, アセトン、エーテル,ベンゾール,トル オール，クロロフォルム，二硫化炭素などには舆く溶ける。

分 析

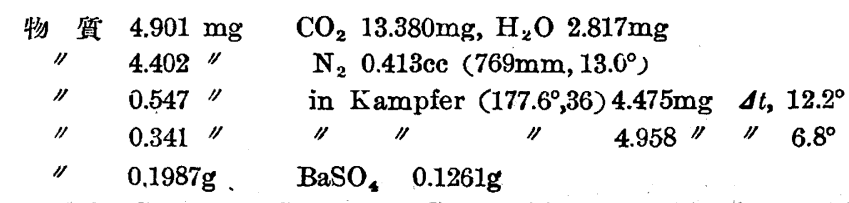

計筑值 $\mathrm{C}_{23} \mathrm{H}_{25} \mathrm{~N}_{3} \mathrm{~S}$ に對して C $73.90 \%, \mathrm{H} 6.68 \%, \mathrm{~N} 11.23 \%, \mathrm{~S} 8.54 \%, \mathrm{M} 374$

實驗值 74.45 ” 6.39 ” $11.33^{\prime \prime} \quad 8.72$ " 361

364

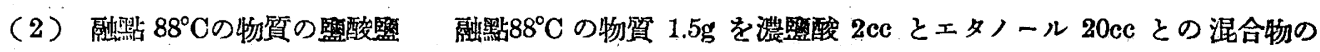
中に加熱溶解せしめ 30 分の後水 15〜20cc を加へ加熱の上滤過冷却すれば淡黄色薄板狀の結晶を得。これを

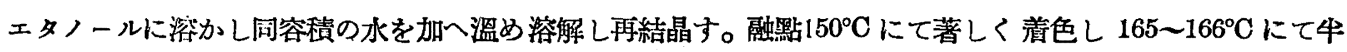
融し餄狀となる。此監は水にもェーテルにも難溶なるがメタノール又はェタノールには良く浴ける。アムモニ ア水に依り $88^{\circ} \mathrm{C}$ の物筫を遊離す。

分 析

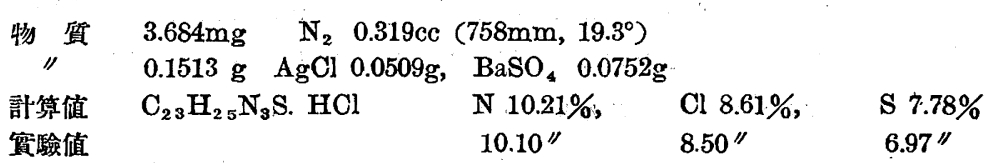

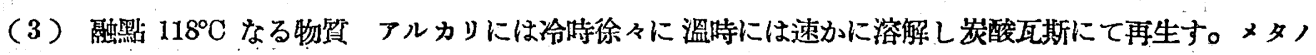
ール，エタノール及び石油エーテルには低溫にて難溶にして高溫には易溶なる故再結晶に適す。赤き結晶, エ ーテル, アセトン, ベンゾール,トルォール等には度く溶解す。

分 析

物 犋 $3.206 \mathrm{mg} \mathrm{CO}_{2} 7.523 \mathrm{mg}, \mathrm{H}_{2} \mathrm{O} 1.546 \mathrm{mg}$

" $3.256 " 1$ " $\mathrm{N}_{2} 0.266 \mathrm{cc}\left(76 \mathrm{2mm}, 21.7^{\circ}\right)$

" $\quad 0.1913 \mathrm{~g} \quad \mathrm{BaSO}_{4} 0.30 \div 2 \mathrm{~g}$

" $\quad 0.276 \mathrm{mg}$ in Kampfer $\left(177.6^{\circ}, 36\right) 2.780 \mathrm{mg} \quad \Delta t, 11.4^{\circ}$

計算值 $\mathrm{C}_{16} \mathrm{H}_{16} \mathrm{~N}_{2} \mathrm{~S}_{2}$ K對して C $64.00 \%, \mathrm{H} 5.33 \%, \mathrm{~N} 9.33 \%, \mathrm{~S} 21.35 \%, \quad \mathrm{M} 300.0$

宽测值 $64.00^{\prime \prime} 5.36^{\prime \prime} 9.48^{\prime \prime} \quad 21.70 " 2313.7$

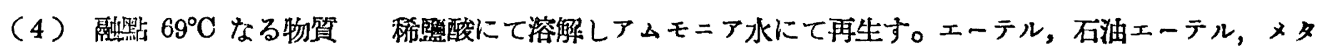

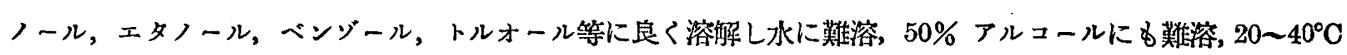

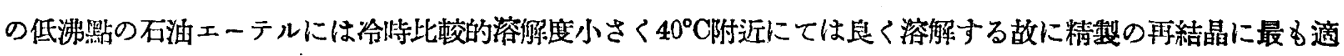
當なり，白色短杜狀（ザラメ狀）に結晶す。

分 析

$\begin{array}{llll}\text { 質 } & 5.213 \mathrm{mg}, & \mathrm{CO}_{2} & 15.492 \mathrm{mg}, \mathrm{H}_{2} \mathrm{O} 3.600 \mathrm{mg} \\ " & 5.251^{\prime \prime} & \mathrm{N}_{2} & 0.524 \mathrm{cc}\left(761 \mathrm{~mm}, 17.1^{\circ}\right) \\ \prime \prime & 0.485^{\prime \prime} & \text { in Kampfer }\left(177.6^{\circ}, 36\right) 4.840 \mathrm{mg} \quad \Delta t, 16.0^{\circ}\end{array}$

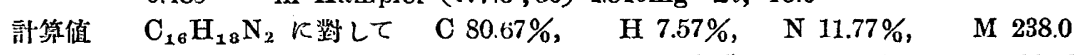

宽湘值 81.04 ” $7.67 ” 211.78$ ” 230.0 